\title{
ANCYLOTHERIUM PENTELICUM (PERISSODACTYLA, MAMMALIA) FROM THE UPPER MIOCENE OF CENTRAL AND WESTERN TURKEY
}

\author{
GERÇEK SARAÇ, TANJU KAYA \& DENIS GERAADS
}

SARAÇ G., KAYA T. \& GERAADS D. Ancylotherium pentelicum (Perissodactyla, Mammalia) from the Upper Miocene of central and western Turkey. Ancylotherium pentelicum (Perissodactyla, Mammalia), une espèce du Miocène supérieur de la Turquie centrale et occidentale.

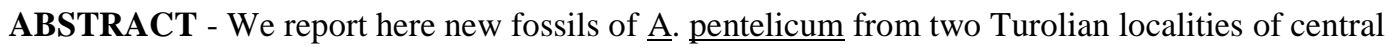
and western Turkey, Pinaryaka and Salihpasalar (Kemikalan). The material, which consists of well preserved distal limb-bones, is compared with the few previously described specimens, mainly from Samos, but the observed differences should probably be attributed to individual variation. There is no evidence of evolution of the species during the Middle Turolian of the Eastern Mediterranean, where it filled a narrow ecological niche, before its extinction.
\end{abstract}

KEYWORDS: CHALICOTHERIIDAE, ANCYLOTHERIUM, LATE MIOCENE, PALEOENVIRONMENT, TURKEY

RÉSUMÉ - Nous décrivons ici de nouveaux fossiles de $\underline{\text { A. pentelicum provenant de deux localités }}$ turoliennes de Turquie centrale et occidentale, Pinaryaka et Salihpasalar (Kemikalan). Le matériel, constitué d'éléments des segments distaux des membres, est comparé aux quelques pièces déjà décrites, provenant surtout de Samos, mais les différences observées sont surtout dues à la variation individuelle. Rien ne suggère que cette espèce ait évolué au cours du Turolien moyen de Méditerranée orientale, où elle occupait une niche écologique restreinte, avant son extinction.

MOTS-CLÉS: CHALICOTHERIIDAE, ANCYLOTHERIUM, MIOCÈNE SUPÉRIEUR, PALEOENVIRONNEMENT, TURQUIE

\section{INTRODUCTION}

Ancylotherium pentelicum is a characteristic but rare constituent of the Turolian fauna of Pikermi (type locality) and Samos, and also known in some other localities, mainly in the Eastern 
Mediterranean. We decribe here new and abundant Ancylotherium material from Ankara-AyasPinaryaka and Mugla-Yatagan-Salihpasalar (Kemikalan) (Fig. 1).

The Late Miocene Pinaryaka fauna (1/25 000 Bolu H28-c2, N 4111 51.6 E 3229 26.1) consists of

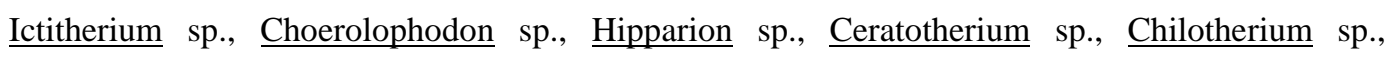
Microstonyx sp., Protoryx sp., Gazella sp. and Oioceros sp., on the basis of preliminary identifications. The Turolian Salihpasalar fauna (1/25 000 Denizli N20-b4, N 371531.2 E 2816 16.0) comprises Crocuta eximia ROTH \& WAGNER, Cremohipparion matthewi (ABEL), Cremohipparion mediterraneum (ROTH \& WAGNER), Ceratotherium neumayri (OSBORN),

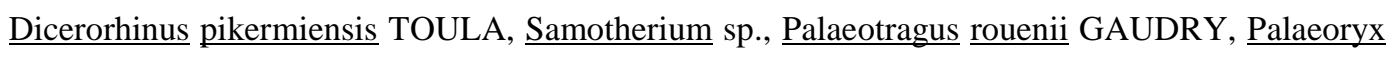
pallasi GAUDRY, Protoryx carolinae MAJOR, Sinotragus n.sp., Gazella depertida GERVAIS and Pliocervus sp. (Atalay 1980; Kaya 1991; Geraads et. al. in press). Ancylotherium (Ancylotherium) pentelicum had not been recorded previously reported from the Pinaryaka and Salihpasalar localities.

The terminology is based on Butler (1965) and Coombs (1978). The material is stored in the Natural History Museum (MTA, Ankara). Abbreviations used are : Pikermi (PIK), Samos (SAM), Metacarpal (Mc), Metatarsal (Mt), Length (L), Width (W), antero-posterior diameter (DAP), proximal antero-posterior diameter (DAP prox.), distal antero-posterior diameter (DAP dis.), transverse diameter (DT), proximal transverse diameter (DT prox.), distal transverse diameter (DT dis.), transverse diameter of shaft in the middle (DT middle), antero-posterior diameter of shaft in the middle (DAP middle).

\section{PALEONTOLOGY}

Order: PERISSODACTYLA Owen, 1848

Family: CHALICOTHERIIDAE Gill, 1872

Subfamily: SCHIZOTHERIINAE Holland and Peterson, 1914

Genus: Ancylotherium GAUDRY, 1862

Ancylotherium (Ancylotherium) pentelicum (GAUDRY \& LARTET, 1856)

Figures 2-4

Material from Pinaryaka - Right and left scaphoid (AAP-42, AAP-40), left lunate (AAP-37), right trapezoid (AAP-44), left magnum (AAP-41), right and left Mc-III (AAP-47, AAP-50), right and left Mc-IV (AAP-48, AAP-49), right astragalus (AAP-53); two left Mt-II (AAP-60, AAP-54); two duplexes (AAP-51, AAP-52), proximal phalanx of digit III of the manus (AAP-57); proximal phalanx of digit IV of the manus (AAP-56); second phalanx (AAP-58); third phalanx (AAP-59). 
Material from Salihpasalar - Right astragalus (MYS-740), left Mt-II (MYS-1852 or 1851), right Mt-III (MYS-757), second phalanx ( MYS-2434).

\section{Description and comparisons}

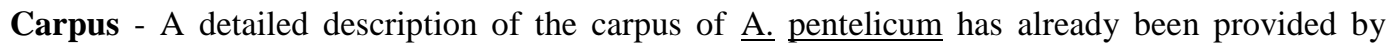
Schaub (1943), and here are mainly noted some differences from the material from Samos and Pikermi, as well as from $\underline{\mathrm{A}}$. hennigi (DIETRICH) from the Plio-Pleistocene of East Africa.

Scaphoid (Fig. 2.2)- The bones are proximodistally flattened (Table 1). The radius facet is trapezoidal and slightly convex in the dorso-volar direction. The trapezoid facet is large, ovoidshaped and concave at the rear. The magnum facet is band-shaped and dorsally narrower. On the lateral side, there are two facets for the lunate, which are separated by a narrow groove. The volar process is square and weak. There is no trapezium facet on the mediovolar side.

\begin{tabular}{|c|c|c|c|c|}
\hline & \multicolumn{3}{|c|}{ A. (․․) pentelicum } & \multirow{2}{*}{$\frac{\text { A. }}{\text { Olduvai }^{2} \text { ) }}$} \\
\hline & AAP-40 & AAP-42 & $\left.\mathrm{SAM}^{1}\right)$ & \\
\hline DT & 72 & 76 & 78 & 64.5 \\
\hline DAP & 81 & 80 & 84.5 & 75.5 \\
\hline lateral $\mathrm{H}$ & 51 & 46 & 52 & 48 \\
\hline medial $\mathrm{H}$ & 29 & 27 & 24.5 & - \\
\hline
\end{tabular}

TABLE 1 - Measurements (mm) of scaphoid of Ancylotherium species. 1) Schaub 1943; 2) Butler 1965. Dimensions des scaphoïdes.

A. (A.) pentelicum differs from $\underline{\text { A. }}$ hennigi from Olduvai Bed-I (Butler 1965, Fig. 21) by having a rectangular trapezoid facet and widely separated lateral facets. It differs from Moropus elatus MARSH from Agate Springs and Tylocephalonyx skinneri COOMBS from Sheep Creek, which bear a trapezium facet and a much deeper scaphoid (Coombs 1978, 1979). 
Lunate (Fig. 2.3)- The radius facet is oval and strongly convex in the dorso-volar direction. On the medial side, two proximal facets for the scaphoid are present. The volar process is shorter (Table 2) than that of the Samos specimen (Schaub 1943, Fig.6). The distal surface is square, and consists of two facets for the magnum and the unciform. The magnum facet is convex in its dorsal part and concave in its volar part. The unciform facet is convex dorsally and separated by a ridge from the magnum facet. This ridge forms a pointed tip on the dorsal side. On the lateral side, the pyramidal facet is band-shaped and separated by a weak ridge from the unciform facet. In lateral view, the profile of the distal surface is more sigmoid than that of the Samos specimen.

\begin{tabular}{|lll|l|}
\hline & \multicolumn{2}{l|}{ A. $(\underline{\text { A. }})$ pentelicum } & A. $\underline{\text { hennigi }}$ \\
& AAP-37 & SAM $^{1}$ ) & Olduvai $^{2}$ ) \\
\hline DT & 63 & 62 & 64 \\
DAP & 66 & 68 & 58 \\
H & 70 & 71 & 61 \\
\hline
\end{tabular}

TABLE 2 - Measurements of lunate of Ancylotherium species.1) Schaub 1943; 2) Butler 1965. Dimensions des semi-lunaires.

The Pinaryaka material differs from $\underline{\text { A }}$. hennigi which has a rhomboidal proximal surface (Butler

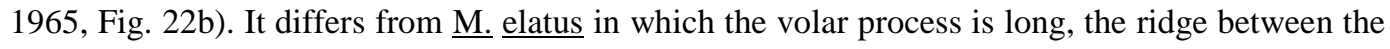
magnum and the unciform is diagonal, and the cuneiform facet forms a D-shaped tongue (Coombs 1978).

Trapezoid (Fig. 2.4)- In proximal view, this bone is not so clearly triangular as the one from Samos (Schaub 1943, Fig.12), because the proximo-volar articular facet for the scaphoid is more rounded, almost hemispherical, and because the dorsal process is broader (Table 3).

\begin{tabular}{|lll|}
\hline & AAP-44 & SAM $^{1}$ ) \\
\hline DAP max & 90 & 86 \\
DT max & 61 & 72 \\
\hline
\end{tabular}

TABLE 3 - Measurements of the trapezoid of A. (‥) pentelicum. 1) Schaub 1943. Dimensions des trapézoïdes. 
Magnum (Fig. 3.4)- The main difference from the Samos specimen (Schaub 1943, Fig. 13) is the strong reduction of the dorsal, non-articular protuberance. It is hook-shaped and strongly compressed transversely between the trapezoid and unciform (Table 4). This reduction is certainly linked with the broader dorsal process of the trapezoid. The volar hook is even more reduced than in $\underline{\text { Moropus, }}$ and contrasts with the very strong process in Tylocephalonyx.

\begin{tabular}{|lll|}
\hline & AAP-41 & SAM $^{1}$ ) \\
\hline DAP max & 107.5 & 108 \\
DT max & 47.5 & 54.5 \\
H max & 65 & 64 \\
& & \\
\hline
\end{tabular}

TABLE 4 - Measurements of the magnum of $\underline{\text { A. }}$ (A.) pentelicum. 1) Schaub 1943. Dimensions des magnums.

Mc-III (Fig. 2.1)- The proximal part of the dorsal surface of the bone is rugose. The magnum facet is rectangular, concave transversally and separated by a weak ridge from the Mc-II facet. The Mc-II facet forms a single facet, and is strongly inclined dorsally. The Mc-lV facet is deeply concave in the dorso-volar direction. The shaft of the Mc-III is flattened with a longitudinal groove on the dorsal surface and a strong volar ridge, which is better defined than in the specimen from Samos. The distal head of the bone is asymmetrical and larger than the proximal one (Table 5). However, the difference is not so conspicuous as in the Samos specimen.

The Mc-III is close to that of A. hennigi, but in the latter species the dorsal longitudinal groove is less marked (Butler 1965). M. elatus differs from $\underline{A}$. (‥) pentelicum by having two Mc-IV facets (Coombs 1978).

\begin{tabular}{|lllll|}
\hline & \multicolumn{2}{l|}{ A. $(\underline{A}$.$) pentelicum$} & & \\
& AAP-47 & AAP-50 & SAM $^{1}$ ) & SAM $^{1}$ ) \\
\hline L & 288.0 & - & 294 & 276 \\
DT prox. & 66.0 & 64.0 & - & 59 \\
DAP prox. & 78.0 & 76.0 & - & - \\
DT middle & 61.0 & 61.0 & 61 & 59 \\
DAP middle & 40.0 & 34.0 & - & - \\
DT dis. & 75.0 & - & 88 & 74 \\
DAP dis. & 84.0 & - & 74 & 83 \\
\hline
\end{tabular}

TABLE 5 - Measurements of the Mc-III of $\underline{\text { A. }}$ (…) pentelicum. 1) Schaub 1943. Dimensions des Mc-III. 
Mc-IV (Fig. 2.1) - The Mc-IV is shorter than Mc-III, while they are of the same length in the Samos specimen. The outline of the proximal surface is almost circular. The unciform facet is triangular, with a volar apex, and is concave transversely. It is inclined dorsally and separated by a sharp ridge from the Mc-III facet. The Mc-III facet is convex in the dorso-volar direction. The proximal end of the Samos specimen is much broader, and the unciform facet is more trapezoidal. However, Schaub (1943) noticed the variability of this epiphysis. The proximal part of the shaft is rugose. The proximo-lateral tubercle is strong. The dorso-medial surface of the bone has a longitudinal rugose area, which tapers above the distal tubercle. The shaft is triangular in crosssection and narrower in the medial side. It bears a longitudinal groove on the dorsal surface. The distal head is slightly asymmetrical and smaller than the proximal one (Table 6). The lateral tubercle is larger than the medial one.

\begin{tabular}{|lllll|}
\hline & \multicolumn{2}{l}{ A.(A.) pentelicum } & & \\
& AAP-48 & AAP-49 & SAM $^{1}$ ) & PIK $^{1}$ ) \\
\hline L & 270 & 280 & 274 & 244 \\
DT prox. & 81 & 77 & 83 & 70 \\
DAP prox. & 74 & $(72)$ & - & - \\
DT middle & 56 & 57 & 54 & 43 \\
DAP middle & 41 & 47 & - & - \\
DT dis. & 63 & 66 & 74 & 66 \\
DAP dis. & 77 & 82 & 79 & 67 \\
\hline
\end{tabular}

TABLE 6 - Measurements of Mc-IV of A. (‥) pentelicum. 1) Schaub 1943. Dimensions des McIV.

Astragalus (Fig. 3.5)- The astragalus is much broader than high (Table 7). The neck of the astragalus is short. On the volar side, the ectal facet for the calcaneum is deeply concave, and extends more than half the transverse width of the astragalus. The calcaneal facet is small and convex. The sustentacular facet is oval in shape and slightly convex. On the distal side, the navicular facet is long in the transverse direction, and convex in the dorso-volar direction. There is no articular facet for the cuboid, as in all Schizotheriinae except Borissiakia. The astragalus trochlea is more symmetrical at Salihpasalar than at Pinaryaka. The latter is similar to the astragalus from Pikermi illustrated by Zapfe (1979, Fig.121) except that the navicular facet is transversally longer. However, other specimens from Pikermi (Coombs, pers.comm.) and Kalimanci (Geraads et. al. in press) are more symmetrical. The astragalus is similar to that of $\underline{A}$. hennigi, but the latter has a thicker lateral part (Guérin 1987, Fig. 9.1). 


\begin{tabular}{|c|c|c|c|c|c|}
\hline & \multicolumn{3}{|c|}{ A. (吕.) pentelicum } & \multirow{2}{*}{$\begin{array}{l}\text { A. hennigi } \\
\text { Laetoli }^{2} \text { ) }\end{array}$} & \multirow{2}{*}{$\begin{array}{l}\text { A. }(\underline{M} .) \text { fraasi } \\
\left.\text { Steinheim }{ }^{3}\right)\end{array}$} \\
\hline & AAP-53 & MYS-740 & $\mathrm{PIK}^{1}$ ) & & \\
\hline DT & 101 & 108 & 122 & 101.5 & 79 \\
\hline DAP & 57 & 46 & - & 59 & - \\
\hline Lateral $\mathrm{H}$ & 61 & 63 & 78 & - & 45 \\
\hline Medial H & 70 & 65 & 79 & 65 & 56 \\
\hline Middle $\mathrm{H}$ & 40 & 37 & - & - & 37 \\
\hline DT dis. & 76 & 85 & - & 85 & - \\
\hline DAP dis. & 48 & 46 & - & 38.5 & - \\
\hline
\end{tabular}

TABLE 7 - Measurements of astragali of Ancylotherium species. 1) Zapfe 1979; 2) Guérin, 1987; 3) Koenigswald 1932. Dimensions des astragales.

Mt-II (Fig. 3.1, 3.2)- Metatarsals are smaller than the metacarpals. The proximal surface of metatarsal-II, which bears the mesocuneiform facet, is square on AAP-60, but triangular on AAP54 and MYS-1852, and concave transversely in all cases. On the lateral side, the mesocuneiform facet is separated by an acute ridge from the ectocuneiform facet, which is concave and extends in the dorso-plantar direction. Distally the ectocuneiform facet merges into a low and band-shaped Mt-III facet. A strong dorso-lateral tubercle and a triangular concave rugose area occur below the Mt-III facet. The medial and dorsal surfaces of the bone are rugose. A longitudinal ridge is strongly developed on AAP-54, and extends along the medial side of the dorsal surface of the bone. The cross-section of the shaft is circular (Table 8). The distal end is separated from the shaft by a shallow groove. There is a strong crest above the distal end on MYS-852 and AAP-54.

The material from Salihpasalar, and probably also AAP-54 belong to young or female individuals, and are less massive than AAP-60, which resembles more the Mt-II from Kemiklitepe (Sen 1994, Fig. 5) and Pikermi (Gaudry 1862, Pl. 20; Zapfe 1979, Fig 127).

\begin{tabular}{|c|c|c|c|c|c|c|c|}
\hline & A. (A.) p & telicum & & & & & \\
\hline & AAP-60 & AAP- 54 & MYS-1852 & $\mathrm{UEK}^{1}$ ) & $\mathrm{PIK}^{2}$ ) & $\mathrm{PIK}^{3}$ ) & $\mathrm{PIK}^{4}$ ) \\
\hline $\mathrm{L}$ & 129 & 126 & 125 & 125 & 130 & - & 111.5 \\
\hline $\begin{array}{l}\text { DT } \\
\text { prox. }\end{array}$ & 46 & - & 38 & 48 & 26 & 44 & - \\
\hline $\begin{array}{l}\text { DAP } \\
\text { prox. }\end{array}$ & 52 & 53 & 48 & 49 & 40 & 53 & 44.5 \\
\hline $\begin{array}{l}\text { DT } \\
\text { middle }\end{array}$ & 41 & 37 & - & 25 & - & - & 31 \\
\hline $\begin{array}{l}\text { DAP } \\
\text { middle }\end{array}$ & 43 & 30 & - & 30 & - & - & - \\
\hline $\begin{array}{l}\text { DT } \\
\text { dis. }\end{array}$ & 52 & 42 & 40 & 54 & 50 & 57 & - \\
\hline DAP & 59 & 60 & 52 & 64 & - & 52.5 & 49.5 \\
\hline
\end{tabular}


dis.

TABLE 8- Measurements of Mt-II of $\underline{A}$. (…) pentelicum. 1) Sen 1994; 2) Gaudry 1862; 3) Zapfe 1979; 4) MNHN. Dimensions des Mt-II.

Mt-III (Fig. 3.3)- This bone is dorsally flat. The proximal surface for the ectocuneiform is triangular and flat. On the medial side, it is separated from the Mt-II facet by a strong crest. The Mt-II facet is low and narrow in the dorso-plantar direction. On the lateral side, the Mt-IV facet is deeply concave. The lateral surface of the bone bears a strong rugosity, which narrows in the distal direction. The distal end is asymmetrical and narrower than the proximal one (Table 9). The plantar articulation for the sesamoid is large.

\begin{tabular}{|c|c|c|c|}
\hline & $\underline{\mathrm{A}} .(\underline{\mathrm{A}}$. pe & elicum & \\
\hline & MYS-757 & $\mathrm{PIK}^{1}$ ) & $\mathrm{PIK}^{2}$ ) \\
\hline $\mathrm{L}$ & 140 & 170 & 140 \\
\hline DT prox. & 46 & 58 & 48 \\
\hline DAP prox. & 43 & 55 & 45 \\
\hline DT middle & 39 & - & - \\
\hline DAP middle & 29 & - & - \\
\hline DT dis. & 36 & 56 & 47 \\
\hline DAP dis. & 54 & - & 57 \\
\hline
\end{tabular}

TABLE 9 - Measurements of Mt III of A. (A.) pentelicum. 1) Gaudry 1862; 2) Zapfe 1979. Dimensions des Mt-III.

Duplex (Fig. 4.2, 4.3)- A large and fused proximal and medial phalanx of digit II of the manus is common in the Schizotheriinae, such as Ancylotherium, Tylocephalonyx, Moropus and Phyllotillon. The Mc-II facet is heart-shaped, concave, and faces proximo-dorsally. It occupies half of the dorsal surface of the first phalanx. The proximal part of the duplex consists of two lobes. The lateral lobe and its volar tubercle are stronger than the medial ones. There is a notch between them for ligament insertion. The border of the medial lobe is swollen. The intermediate volar tuberosity is distinguishable. The distal trochlea is deep (Table 10).

\begin{tabular}{|c|c|c|c|c|c|c|}
\hline & \multicolumn{4}{|c|}{$\underline{\text { A. }}$ (A.) pentelicum } & \multirow{2}{*}{$\begin{array}{l}\text { A. } \mathrm{sp} . \\
\left.\mathrm{Ka}^{2}\right)\end{array}$} & \multirow{2}{*}{$\begin{array}{l}\underline{\mathrm{A}} .(\underline{\mathrm{M}} .) \mathrm{sp} . \\
\left.\mathrm{Ke}^{3}\right)\end{array}$} \\
\hline & AAP-51 & AAP-52 & $\mathrm{PIK}^{1}$ ) & $\mathrm{SAM}^{1}$ ) & & \\
\hline $\mathrm{L} \max$ & 178 & 182 & 170 & 182 & 121 & 129 \\
\hline
\end{tabular}




\begin{tabular}{|lcccc|l|l|} 
DT prox. & 74 & 72 & 67 & 67 & 51 & 40 \\
DT art. prox. & 68 & 66 & - & - & - & - \\
DT dis. & 51 & 61 & - & - & - & - \\
DAP dis. & 88 & 86 & 86 & 85 & 63 & 60 \\
L phal. I & 122 & 124 & 111 & 119 & 83 & 90 \\
\hline
\end{tabular}

TABLE 10 - Measurements of duplex of digit II of manus of Ancylotherium. 1) Schaub 1943; 2) Ka-Kaisersteinbruch, Zapfe 1967; 3) Ke-Krems, Zapfe 1974. Dimensions des duplex.

The duplexes of $\underline{\mathrm{A}}$. (…) pentelicum are larger than those of $\underline{\mathrm{A}}$. (Metaschizotherium). $\underline{\mathrm{A}}$. $(\underline{\mathrm{A}}$.

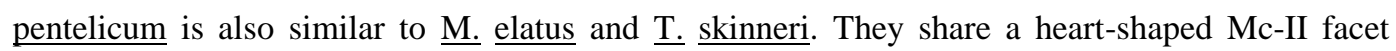
facing proximo-dorsally. However, $\underline{T}$. skinneri differs from A. (A.) pentelicum by having a curved junction between the proximal and medial phalanxes, and a strongly developed proximo-volar tubercle (Coombs 1979).

First phalanx (Fig. 4.1) - Both larger proximal phalanxes are related to the manus. One proximal phalanx (AAP-57 Fig. 4.1) belongs to digit III and the other to digit IV. The proximal facet for the metacarpal is heart-shaped, and faces proximo-dorsally. It occupies less than one-third of the dorsal length. In dorsal view, the phalanxes taper distally. The proximo-volar tubercle is strong. Two lobes separated by a deep notch are present in the proximal part. Two strong marginal ridges, with a broad longitudinal concavity between them, extend along the volar surface of the phalanx. The intermediate volar tubercle is strong. The distal part is asymmetrical.

\begin{tabular}{|c|c|c|c|}
\hline & \multicolumn{3}{|c|}{ A. (‥) pentelicum } \\
\hline & $\begin{array}{l}\text { AAP-57 } \\
\text { digit III }\end{array}$ & $\begin{array}{l}\text { AAP-56 } \\
\text { digit IV }\end{array}$ & $\begin{array}{l}\mathrm{HAL}^{1} \text { ) } \\
\text { digit III }\end{array}$ \\
\hline $\mathrm{L}$ & 125 & 105 & 122 \\
\hline DT prox. & 61 & 61 & 57 \\
\hline DAP prox. & 75 & 70 & 71 \\
\hline DT middle & 51 & 51 & 44 \\
\hline DAP middle & 49 & 44 & 35 \\
\hline DT dis. & 46 & 45 & 44 \\
\hline DAP dis. & 37 & - & 36 \\
\hline
\end{tabular}

TABLE 11- Measurements of first phalanxes of digit III and digit IV of the manus of $\underline{\text { A. }}$ (A.) pentelicum. 1) HAL-Halmyropotamos (Melentis 1970). Dimensions des premières phalanges. 


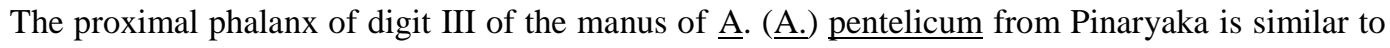
that of $\underline{A}$. pentelicum from Halmyropotamos (Melentis 1970) (Table 11). $\underline{\text { A. }}$ ( A.) pentelicum also generally resembles $\underline{\text { A. }}$ (‥) fraasi (Koenigswald 1932; Pl 2, Fig. 21) and ‥ elatus (Coombs 1978). They share a proximo-dorsal metacarpal facet, which occupies less than one-third of the dorsal surface.

Second phalanx - Second phalanxes are referred to digit III-IV of the manus. The proximal surface consists of two concave facets for the first phalanx, which are separated by a weak median ridge. The medial facet is larger transversally than the lateral one (Table 12). The medial and lateral sides of the second phalanx have deep grooves in the middle parts.

\begin{tabular}{|lll|}
\hline & \multicolumn{2}{l|}{ A. (A.) pentelicum } \\
& AAP-58 & MYS-2434 \\
\hline L & 69 & 61 \\
DT prox. & 48 & 44 \\
DAP prox. & 56 & 53 \\
DT middle & 46 & 50 \\
DAP middle & 42 & 38 \\
DT dis. & 44 & 36 \\
DAP dis. & 62 & 60 \\
\hline
\end{tabular}

TABLE 12 - Measurements of second phalanx of $\underline{\mathrm{A}}$. (…) pentelicum. Dimensions des deuxièmes phalanges.

Third phalanx (Fig. 4.4)- The large third phalanx of digit II of the manus is taller, transversely flatter, and slightly larger at the base than those of other fingers (Table 13). All surfaces of the phalanx have deep sulci, and are rugose. The facet for the duplex is deeply concave and divided by a median ridge. There is a strong subungual tuberosity and two foramina below the facet. The third phalanx is asymmetrical and split by a deep cleft, which is deeper dorsally. The dorsal process is strong. The claws have sharp dorsal edges.

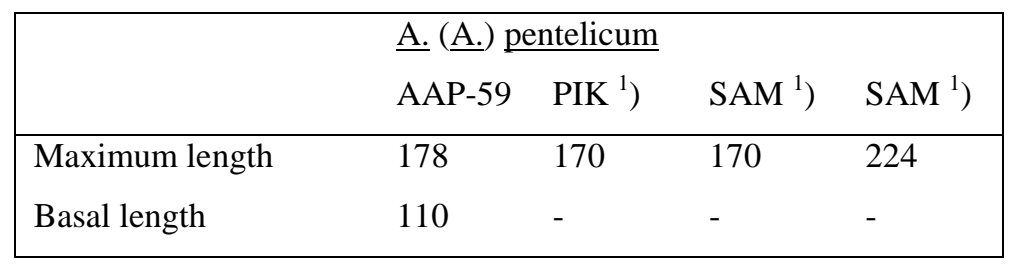




\begin{tabular}{|lllll|}
\hline Basal width & 56 & 56 & 54 & 57 \\
Width of articulation & - & - & - & - \\
Height of articulation & 87 & 70 & 75 & 74 \\
\hline
\end{tabular}

TABLE 13 - Measurements of the third phalanx of $\underline{\text { A. }}$ (A.) pentelicum. 1) Schaub 1943. Dimensions des troisièmes phalanges.

The third phalanxes are close to those from Samos (Schaub 1943, Fig. 21) and Pikermi (Gaudry

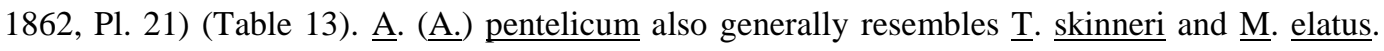
They share a transversely compressed, large and rugose subungual process. However, $\underline{\mathrm{T}}$. $\underline{\text { skinneri }}$ is characterised by a broader base (Coombs 1979, Fig. 27).

\section{Paleoecology}

In Eurasia, the Late Miocene is the time of a change from tropical and sub-tropical vegetation to a more open environment, perhaps similar to a savanna (but see Solounias et al. 1999). Indeed, the Late Miocene (Turolian) faunal assemblages of Anatolia, which are characterised by Hipparion, $\underline{\text { Ceratotherium, }} \underline{\text { Chilotherium, }}$ Choerolophodon, Samotherium and a variety of spiral-horned antelopes (Becker-Platen et al. 1975; Kaya 1986; Sen et al. 1994), consist mainly of grazers or mixed feeders, indicating open environments certainly dominated by mosaics of habitats. Ancylotherium pentelicum is usually associated with this kind of faunal assemblage, rather than with Suids, Tragulids, Deinotheres, or Hominoids (Bonis et al., 1999), and this certainly reflects its preference for open landscapes. However, $\underline{A}$. $(\underline{A}$.) pentelicum is never common in any fossil locality suggesting a life assemblage of restricted variety. In addition, ecology of this species was certainly quite different from that of the above-mentioned genera. Indeed, it was certainly not a grazer because, although the labial wall of the upper molars is high, the lingual part remains low, and the molarization of the premolars has not been brought much further than in the Chalicotheriinae. The long molars are indicative of a coarse diet (Coombs 1978), probably comprising twigs and small branches (Borissiak 1945; Schaub 1943). A. (…) pentelicum was certainly less selective than other browsers living in open country, such as the giraffe or gerenuk, and its feeding preferences were perhaps more like those of Diceros.

\section{CHRONOLOGY}

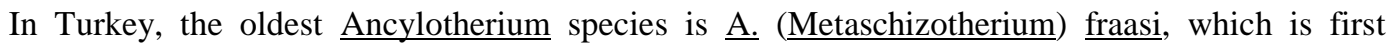
recognized in the lower Astaracian strata in Mugla (Kultak) (Kaya et al. in press.). $\underline{\text { A. }}$ (․․) 
pentelicum is a more evolved element of the classic Late Miocene (Turolian) faunas. In Turkey, it has previously been reported from Kemiklitepe-B (Kaya 1988; Sen 1994), and is also present in Gülpınar (Kaya 1986). In Spain A. (‥) pentelicum is known on the basis of limited specific data (Sondaar 1961). On the grounds of sound evidence, the species is recorded from several Late Miocene (Turolian) localities in Europe, such as Pikermi (Gaudry 1862; Thenius 1953), Halmyropotamos (Melentis 1970) and Samos (Schaub 1943) in Greece, Titov Veles in Macedonia (Garevski \& Zapfe 1988) Kalimanci, Gorna Sushitsa and Hadjidimovo in Bulgaria (Bakalov 1955; Geraads et. al., in press), Novo-Ukrainka in Ukraine (Pidoplichko 1959: In Coombs 1989), Maragheh in Iran (Mecquenem 1924), Molayan in Afghanistan (Brunet et al. 1984) (Fig. 5). Even though the biochronology of these localities is still imperfectly settled, there is no evidence that any of them is earlier than the Turolian, and any of them later than MN 12 equivalent. Thus, $\underline{\mathrm{A}}$. pentelicum might have a very restricted time-range, and a Turolian age can be assigned to the Pinaryaka fauna, which is in agreement with the rest of the faunal data from this site.

\section{CONCLUSIONS}

Ancylotherium (Ancylotherium) pentelicum from Pinaryaka and Salihpasalar is morphologically similar to that of Pikermi and Samos, although there are some differences. Compared to Samos, the volar process of the scaphoid is weaker and smaller, the volar process of the lunate is shorter and the magnum is strongly compressed transversely. These are probably derived features, but the Mc-III is longer than the Mc-IV, which is certainly primitive. The astragalus displays the same variability as at Pikermi. Thus, there seem to be no consistent difference of evolutionary stage from one site to another. This suggests that by the Late Miocene $\underline{A}$. ( $\underline{\text { A. }}$ ) pentelicum had reached the end of its evolutionary line, and that the later $\underline{A}$. hennigi from East Africa, as noticed by Butler (1965), is not derived directly from it.

The occurrence of $\underline{\mathrm{A}}$. (‥) pentelicum in several Turolian localities of Central and Western Anatolia confirms that this country is part of the now generally recognized 'Greco-Iranian' (or rather 'Balkano-Iranian') or 'subparatethyan' bioprovince, characterized by the prevalence of a grassland biotope among mosaics of open woodland or savannah. Probably restricted to a narrow ecological niche in these open biotopes, it was probably unable to withstand the ecological changes near the MN 12 - MN 13 transition.

\section{REFERENCES}

ATALAY Z. 1980 - Mugla-Yatagan ve yakin dolayi karasal Neojeninin stratigrafi arastirmasi. Geological Bulletin of Turkey, C. 23: 93-99, Ankara. 
BAKALOW P. 1955 - Chalicotheriidae in Südwest Bulgarien. Bulg. Akad. Wiss. Abt. Geol. Geogr. u. chem. Wiss. Mitt. d Geol. Ins., Sofia, 3:151-159.

BECKER-PLATEN J.D., SICKENBERG O. \& TOBIEN H. 1975 - Vertebraten-Lokalfaunen der Türkei und ihre Altersstellung. Geologisches Jahrbuch B 15: 45-100.

BONIS L. de, BOUVRAIN G. \& KOUFOS G.D. 1999 - Palaeoenvironments of late Miocene primate localities in Macedonia, Greece. In AGUSTI J., ROOK L. \& ANDREWS P. (eds.): Hominoid Evolution and climatic change in Europe. Vol.1. The evolution of Neogene terrestrial ecosystems in Europe, Cambridge University Press:413-436.

BORISSIAK A. 1945 - The Chalicotheres as a biological type. American Journal of Science, 243: 667-679, New Hawen.

BRUNET M., HEINTZ E. \& BATTAIL B. 1984 - Molayan (Afghanistan) and the Khaur Siwaliks of Pakistan: an example of biogeographic isolation of Late Miocene mammalian faunas. Geologie en Mijnbouw, 63:31-38.

BUTLER P.M. 1965 - East African Miocene and Pleistocene Chalicotheres. Fossil mammals of Africa, 18. Bulletin of the British Museum (Natural History) Geology, 10: 163-237, London.

COOMBS M.C. 1978 - Reevaluation of Early Miocene North American Moropus (Perissodactyla, Chalicotheriidae, Schizotheriinae). Bulletin of Carnegie Museum of Natural History, 4: 1-62 , Pittsburg.

COOMBS M.C. 1979 - Tylocephalonyx a new genus of North American dome-skulled Chalicotheres (Mammalia, Perissodactyla). Bulletin of the American Museum of Natural History. 164 (1) 64 p., New York.

COOMBS M.C. 1989 - Interrelationships and diversity in the Chalicotheriidae. In PROTHERO D.R.\& SCHOCH R.M. (eds.): The evolution of Perissodactyls. Oxford University Press: 438457.

GAREVSKI R. \& ZAPFE H. 1988 - Weitere Chalicotheriiden-funde aus der Pikermi-fauna von Titov Veles (Mazedonien, Jugoslawien). Acta Musei Macedonici Scientiarum Naturalium, XVII (1), 140:1-20. 
GAUDRY A. 1862 - Animaux fossiles et géologie de l'Attique. Libraire de la Société géologique, 1-475, Paris.

GERAADS D., SPASSOV, N. \& KOVACHEV D - In press. New Chalicotheriidae (Mammalia) from Bulgaria. Journal of Vertebrate Palaeontology, 21 (2).

GUÉRIN C. 1987 - Chalicotheriidae (Mammalia, Perissodactyla) remains from Laetoli. In M.D.Leakey \& J.M. Harris (eds.): Laetoli: a Pliocene site in Northern Tanzania. Clarendon Press, Oxford. 315-320.

KAYA T. 1986 - Çanakkale ve çevresi Perissodactyla fosilleri (paleontoloji, biyostratigrafi, paleoekoloji ve paleocografya). Ege University Science Faculty, pH thesis (unpublished), 239 p, Izmir.

KAYA T. 1988 - Kemiklitepe (Usak-Esme) memeli faunasındaki Perissodactyla buluntuları. IX. National Biology Congress, I: 355-361, Sivas.

KAYA T. 1991- Mugla yoresindeki Geç Miyosen yasli memeli faunasindaki Perissodactyla bulgulari. Ankara University, Suat Erk Symposium: 1-6, Ankara.

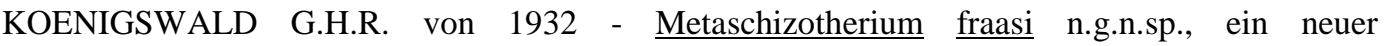
Chalicotheriide aus dem Obermiozan von Steinheim a. Albuch. (Die tertiaren Wirbeltiere des Steinheimer Beckens VIII). Paläontographica Supplement, Bd., 8 Teil VIII: 11-24, Stuttgart.

MECQUENEM R. de 1924 - Contribution a l'étude des fossiles de Maragha. Annales de Paléontologie, v. XIII: 135-160.

MELENTIS J. K. 1970 - Studien über fossile Vertebraten Griechenlands. 28. Die Pikermifauna von Halmyropotamos (Euböa-Griechenlands), Annales Géologiques des Pays Helléniques 5: 217-229. Athen.

PIDOPLICHKO I. G. 1959- New finds of mammals in the Neogene of the Ukraine Dopovidi. Akademie Sciences Ukrainian RSR, N. 5,531-534.

SCHAUB S. 1943 - Die Vorderextremität von Ancylotherium pentelicum GAUDRY \& LARTET. Schweizerische Paläontologische Abhandlungen, 64: 1-36, Basel. 
SEN S. 1994 - Les gisements de mammiferès du Miocène supérieur de Kemiklitepe, Turquie: 5. Rongeurs, Tubulidentés et Chalicothères. Bulletin du Muséum national d'Histoire Naturelle, 4, 16 (1): 97-111.

SEN S., BONIS L. DE., DALFES N., GERAADS D. \& KOUFOS G. 1994 - Les gisements de mammifères $\mathrm{du}$ Miocène supérieur du Kemiklitepe. Turquie: 1. Stratigraphie et magnetostratigraphie. Bulletin du Muséum national d'Histoire Naturelle, 4, 16 (1): 5-19.

SOLOUNIAS N., PLAVCAN J.M., QUADE J. \& WITMER L. 1999 - The paleoecology of the Pikermian Biome and the savanna myth. In AGUSTI J., ROOK L. \& ANDREWS P. (eds.): Hominoid Evolution and climatic change in Europe. Vol.1. The evolution of Neogene terrestrial ecosystems in Europe, Cambridge University Press:436-454.

SONDAAR P. 1961- Les Hipparion de l'Aragón meridional. Estudios Geologicos, 209-305.

THENIUS E. 1953 - Studien über fossile Vertebraten Griechenlands. III. Das Maxillargebiss von Ancylotherium pentelicum GAUDRY und LARTET. Annales Géologiques des Pays Helléniques,5: 97-106, Athen.

ZAPFE H. 1974 - Ein schizotheriiner Chalicotheriidae aus pannonischen Schottern der Umgebung von Krems, Niederösterreich. Sitzungsberichten Österreichischen Akademie der Wissenschaften Mathematisch naturwissenschaftliche Klasse: I, 182:289-299.

ZAPFE H. 1967 - Ancylotherium im Obermiozän des Wiener Beckens. Annalen des Naturhistorischen Museums in Wien, 71: 404-411.

ZAPFE H. 1979 - Chalicotherium grande (BLAINVILLE) aus der miozänen Spaltenfüllung von Neudorf an der March (Děvinská Nová Ves), Tschechoslowakei. Neue Denkschriften des Naturhistorischen Museums in Wien, 2:1-282, Wien.

\author{
G. SARAÇ \\ Maden Tetkik Arama Enstitüsü \\ Mineral Research and Exploration Institute (MTA) \\ 06520 Ankara-Turkey \\ T. KAYA \\ Ege University Natural History Museum \\ 35100 Bornova,Izmir-Turkey \\ E-mail: tanju@sci.ege.edu.tr
}




\section{GERAADS}

UPR 2147 CNRS , 44 rue de l'Amiral Mouchez

75014 Paris-France

dgeraads@ivry.cnrs.fr 